\title{
INVITRO ANTI-OBESITY EFFECT OF MACROLICHENS HETERODERMIA LEUCOMELOS AND RAMALINA CELASTRI BY PANCREATIC LIPASE INHIBITORY ASSAY
}

\author{
RASHMI SHIVANNA ${ }^{1}$, HENGAMEH PARIZADEH ${ }^{2}$, RAJKUMAR H. GARAMPALLI ${ }^{*}$ \\ ${ }^{1}$ Department of Studies in Botany, Manasagangotri, University of Mysore, Mysore 570006, Karnataka, India, ${ }^{2}$ Department of studies in \\ Microbiology, Manasagangotri, University of Mysore, Mysore 570006, Karnataka, India. \\ Email: dr.hgrajkumar@botany.uni-mysore.ac.in \\ Received: 18 Jun 2016 Revised and Accepted: 31 Mar 2017
}

\begin{abstract}
Objective: Obesity is a chronic disorder caused by an imbalance between energy intake and expenditure in which excessive fat will be deposited in adipose tissue and poses a risk to the health and well-being of humans. Agents which inhibit pancreatic lipase play an important role in the treatment of obesity. The aim of this study was to assess the potential effect of macro lichens Heterodermia leucomelos (L.) Poelt a foliose lichen and Ramalina celastri (Sprengel) Krog and Swinscow a fruticose lichen in the treatment of obesity.
\end{abstract}

Methods: In vitro anti-obesity inhibitory effect of macro lichens were evaluated by using chicken pancreatic lipase activity. Lipase was extracted from the chicken pancreas. Different concentrations from $5-25 \mathrm{mg} / \mathrm{ml}$ of methanol and ethyl acetate extracts of lichens Heterodermia leucomelos and Ramalina celastri was incubated with pancreas lipase.

Results: With the increase in the concentration of extracts the higher inhibition of the enzyme was observed. Solvent methanol showed good activity compared to ethyl acetate. Percentage of inhibition ranged from 19.7-69.8 and 20.0-86.6 \% in the methanol extract of Heterodermia leucomelos and Ramalina celastri respectively. Comparatively lichen Ramalina celastri in methanol extract showed maximum inhibition of $86.6 \%$, whereas ethyl acetate showed an inhibition of $63.0 \%$ at $25 \mathrm{mg} / \mathrm{ml}$ against enzyme lipase.

Conclusion: In the present study, the inhibitory activity of lichen indicates its protective role in treating obesity. Molecular sequencing of this lichen helps in future to determine the various metabolic pathways that are responsible for the production of novel compounds.

Keywords: Anti-obesity, Lichen, Lipase, Hyperlipidemia, Ramalina celastri

(C) 2017 The Authors. Published by Innovare Academic Sciences Pvt Ltd. This is an open access article under the CC BY license (http://creativecommons.org/licenses/by/4.0/) DOI: http://dx.doi.org/10.22159/ijpps.2017v9i5.13560

\section{INTRODUCTION}

Obesity is a chronic metabolic disorder caused by an imbalance between energy intake and expenditure. Overweight and obesity are defined as abnormal or excessive fat accumulation that presents a risk to health [1]. Obesity is defined in terms of body mass index (BMI), which is calculated as body weight divided by the square of height [2]. According to WHO, high blood cholesterol level leads to approximately $56 \%$ of cardiac disease worldwide and about 4.4 million deaths each year [3]. Being overweight or obese should be prevented by constant exercise and dietary routines. Nevertheless, when the latter techniques fail in obtaining $10 \%$ weight loss, pharmacological treatment is required. Despite the fact that this alternative is highly recommended, there are controversial results on the use of some pharmacological agents such as sibutramine [4].

Currently available allopathic drugs used in the treatment of hyperlipidaemia are associated with a number of side effects. Drugs like amphetamine, rimonabant and sibutramine licenses have been withdrawn due to an increased risk of psychiatric disorders and non-fatal myocardial infarction or stroke. Even if orlistat is not as effective as other drugs in reducing body weight, orlistat is presently the only available choice for the treatment of obesity because of its safety for cardiovascular events and positive effects on diabetic control [5]. The consumption of synthetic drugs leads to hyperuricemia, diarrhoea, nausea, myositis, gastric irritation, flushing, dry skin and abnormal liver function [6]. Recently, newer approaches to the treatment of obesity have involved inhibition of dietary triglyceride absorption via inhibition of pancreatic lipase as this is the major source of excess calories [7]. More effective and better-tolerated drugs should be developed which much be safe and consumed long-term in the management of obesity.

Pancreatic lipase (PL) is an enzyme, secreted from the pancreas and plays an excellent role in the absorption of triglyceride in the small intestine. Dietary fats are composed of about 95\% triacylglycerol's (TG). Pancreatic lipase hydrolyses the water insoluble triacylglycerol's in the intestinal lumen and thereby used for the dietary fat absorption. Pancreatic lipase inhibitors are considered to be a valuable therapeutic agent for treating diet-induced obesity [8]. One of the screening strategies used in the discovery of anti-obesity drugs is to search for potent lipase inhibitors from natural products. Drugs from natural sources are safer and more efficient, even though they are also toxic, but are of less damaging as compared with the pure synthetic ones. The search for novel natural bioactive compounds as a foundation for new drug discovery is receiving attention as previously reliable standard drugs become less effective against the emerging new strains of multiple drug resistant strains [9].

The aim of our study was to evaluate anti-lipase inhibitory drug from lichens. Lichens are symbiotic organisms of fungal and algal and/or cyanobacterial partner. Lichens are ubiquitous organisms occurring in varied climatic conditions ranging from the poles to the tropics on earth and constitute an important component of terrestrial biodiversity. Lichen synthesises numerous metabolites called lichen substances, including aliphatic, cyclo-aliphatic, aromatic and terpenic components [10]. Lichens and their metabolites have manifold biological activity; antiviral, antibiotic, antitumor, allergenic, plant growth inhibitory, antiherbivore, ecological roles and enzyme inhibitory [11]. The work on lipase inhibitory of lichens are very scanty so an attempt has been made to evaluate the anti-obesity activity of some macro lichens using chicken pancreatic lipase.

\section{MATERIALS AND METHODS}

\section{Collection and identification of lichens}

The lichens selected for this study were collected from Madikeri district, Karnataka. Madikeri lies in the Western Ghats of Karnataka 
and is a popular hill station. It features a tropical highland climate as it has an elevation of 1061 meters (3484 feet). Madikeri is located at $12.42{ }^{\circ} \mathrm{N} 75.73{ }^{\circ} \mathrm{E}$. The collected lichens were identified as Heterodermia leucomelos and Ramalina celastri based on morphological, anatomical and colour tests.

Heterodermia leucomelos (L.) Poelt; a foliose lichen belongs to the family Physciaceae. Thallus foliose, linear, ribbon-like with black rhizinae along margin, attached to substratum by basal or central part, suberect at the periphery, laciniae up to $1.5 \mathrm{~mm}$ wide, lower cortex absent, upper cortex prosoplectenchymatous composed of longitudinally disposed compact hyphae, photobiont a green alga, sorediate or not, apothecia stipitate, lecanorine, hypothecium hyaline, asci 8-spored, spores brown, 2celled, pachysporia type, polyblastidia always present in spores, spores $35-54 \times 18-25 \mu \mathrm{m}$.

Ramalina celastri (Sprengel) Krog and Swinscow; a fruticose lichen belongs to the family Ramalinaceae. Thallus shrubby, moderately branched, surface greenish grey to greenish yellow, smooth, shiny, without soredia. Pseudocyphellae linear, laminal, rarely marginal, cortex thin chondroid strands. Apothecia laminal on one side of the blade, disc flat without pruina, margin concolorous with the thallus, asci 8-spored, ascospores hyaline, 1-septate, fusiform 12-16 x 4-6 $\mu \mathrm{m}$ [12].

\section{Chemicals and reagents}

Ammonium sulphate, Phenolphthalein, Oxalic acid were purchased from Qualigens Fine Chemicals, Mumbai, India. Sucrose was purchased from HiMedia Laboratories, Mumbai, India. Phosphate buffer [Potassium chloride and Potassium dihydrogen phosphate], Sodium hydroxide, Potassium hydrogen phthalate were purchased from E. Merck, Mumbai, India. Methanol, ethyl acetate, acetone, ethanol, olive oil used were of analytical grade.

\section{Preparation of extracts}

Collected lichens were washed with distilled water and kept to dry at room temperature. The dried lichen materials were ground to fine powder and extracted by soxhlet apparatus using methanol and ethyl acetate as solvents. The extracts were filtered using whatman filter paper no. 1. Filtered extracts were concentrated by air-drying for $4-5 \mathrm{~d}$ or until the extracts crystallized, and preserved at $5{ }^{\circ} \mathrm{C}$ in airtight bottles until further use.

\section{Anti-lipase activity of lichens}

\section{Extraction of lipase from chicken (Gallus domesticus) pancreas}

The pancreas of freshly slaughtered chicken was collected, washed thoroughly and placed in ice-cold sucrose solution $(0.01 \mathrm{M})$. The pancreas was homogenized in $0.01 \mathrm{M}$ sucrose and centrifuged. The supernatant solution was separated and subjected to ammonium sulphate precipitation ( $50 \%$ saturation). The obtained white pellets after centrifugation were dissolved in sucrose solution and again saturated with $50 \%$ ammonium sulphate and centrifuged. Finally, pellets were used as enzyme source by dissolving in phosphate buffer (pH 7) [13].

\section{Determination of chicken pancreatic lipase activity}

The chicken pancreatic lipase activity was determined by incubating an emulsion containing $8 \mathrm{ml}$ of olive oil (dietary fat), $0.4 \mathrm{ml}$ of phosphate buffer and $1 \mathrm{ml}$ of chicken pancreatic lipase for an hour. The reaction was stopped by addition of $1.5 \mathrm{ml}$ of a mixture containing acetone and 95\% ethanol (1:1). The amount of liberated fatty acid was determined by titrating the emulsion against $0.02 \mathrm{M}$ sodium hydroxide (standardized by potassium hydrogen phthalate) using phenolphthalein as an indicator. The end point is the appearance of pink colour [14].

\section{Pancreatic lipase inhibitory activity}

Lichen extracts were prepared in different concentrations such as $5,10,15,20,25 \mathrm{mg} / \mathrm{ml}$. A $100 \mu \mathrm{l}$ of each concentration of the sample was mixed with $8 \mathrm{ml}$ of olive oil, $0.4 \mathrm{ml}$ phosphate buffer and $1 \mathrm{ml}$ of chicken pancreatic lipase and it were incubated for $60 \mathrm{~min}$. The reaction was stopped by the addition of $1.5 \mathrm{ml}$ of a mixture containing acetone and $95 \%$ ethanol (1:1).

The appearance of pink colour from yellow colour shows the liberated fatty acids, which was determined by titrating the solution against $0.02 \mathrm{M}$ sodium hydroxide (standardized by 0.01 $M$ oxalic acid) using phenolphthalein as an indicator and the percentage inhibition of lipase activity was calculated using the following formula:

Lipase inhibition percentage

$$
=1-\left\{\frac{\text { Lipase activity before treatment }}{\text { Lipase activity after treatment }}\right\} \times 100
$$

\section{RESULTS}

Pancreatic lipase inhibition is one of the most widely studied mechanisms used to determine the potential efficacy of natural products as anti-obesity agents. Hence, in the present study lipase was isolated from the chicken pancreas and determined the inhibitory activity of pancreatic lipase when incubated with different concentrations from $5,10,15,20,25 \mathrm{mg} / \mathrm{ml}$ of methanol and ethyl acetate extracts of lichens Heterodermia leucomelos (L.) poelt and Ramalina celastri (Sprengel) krog and swiss cow.

With the increase in the concentration of extracts, the higher inhibition of the enzyme was observed. Comparatively lichen Ramalina celastri showed maximum inhibition against enzyme lipase. Solvent methanol extract showed good activity compared to ethyl acetate extract. Lipase activity ranged from $6.23 \pm 0.05$ to $7.30 \pm 0.05$ in methanol extract and $1.36 \pm 0.50$ to $3.50 \pm 0.10$ respectively in methanol and ethyl acetate extracts of Heterodermia leucomelos (table 1).

Whereas Ramalina celastri showed inhibitory activity at concentrations ranging from $6.00 \pm 0.50$ to $8.50 \pm 0.50$ and $4.05 \pm 0.05$ to $6.50 \pm 0.10$ of methanol and ethyl acetate extracts respectively (table 2). Percentage of inhibition ranged from 19.7-69.8 and 20.0$86.6 \%$ in the methanol extract of Heterodermia leucomelos and Ramalina celastri respectively (fig. 1 and 2).

The maximum inhibition observed in Ramalina celastri in methanol extract showed an inhibition of $86.6 \%$ with lipase activity of $6.00 \pm 0.50$ at $25 \mathrm{mg} / \mathrm{ml}$, whereas ethyl acetate showed an inhibition of $62.0 \%$ with lipase activity of $4.05 \pm 0.05$ at $25 \mathrm{mg} / \mathrm{ml}$. The inhibition percentage observed in Heterodermia leucomelos in methanol extract showed an inhibition of $68.8 \%$, whereas ethyl acetate showed an inhibition of $56.2 \%$ with lipase activity of $6.23 \pm 0.05$ and $1.36 \pm 0.05$ at $25 \mathrm{mg} / \mathrm{ml}$ respectively.

Table 1: Lipase activity of lichen Heterodermia leucomelos (L.) poelt

\begin{tabular}{lll}
\hline Concentration of extract $\mathbf{( m g / m l )}$ & Lipase activity & \multicolumn{1}{c}{ Ethyl acetate extract } \\
\cline { 2 - 3 } & Methanol extract & $3.50 \pm 0.10$ \\
\hline 5 & $7.30 \pm 0.50$ & $3.13 \pm 0.05$ \\
10 & $7.16 \pm 0.50$ & $2.53 \pm 0.10$ \\
15 & $7.00 \pm 0.10$ & $1.90 \pm 0.10$ \\
20 & $6.53 \pm 0.05$ & $1.36 \pm 0.05$ \\
25 & $6.23 \pm 0.05$ & 1.05 \\
\hline
\end{tabular}

*Values are in mean \pm standard deviation, $n=3$. 
Table 2: Lipase activity of lichen Ramalina celastri (sprengel) krog and swinscow

\begin{tabular}{lll}
\hline Concentration of extract $(\mathbf{m g} / \mathbf{m l})$ & \multicolumn{2}{l}{ Lipase activity } \\
\cline { 2 - 3 } & Methanol extract & Ethyl acetate extract \\
\hline 5 & $8.50 \pm 0.50$ & $6.50 \pm 0.10$ \\
10 & $7.12 \pm 0.10$ & $5.53 \pm 0.05$ \\
15 & $6.66 \pm 0.10$ & $4.80 \pm 0.10$ \\
20 & $6.10 \pm 0.05$ & $4.26 \pm 0.50$ \\
25 & $6.00 \pm 0.50$ & $4.05 \pm 0.05$ \\
\hline
\end{tabular}

*Values are in mean \pm standard deviation, $n=3$.

\section{H. leucomelos}

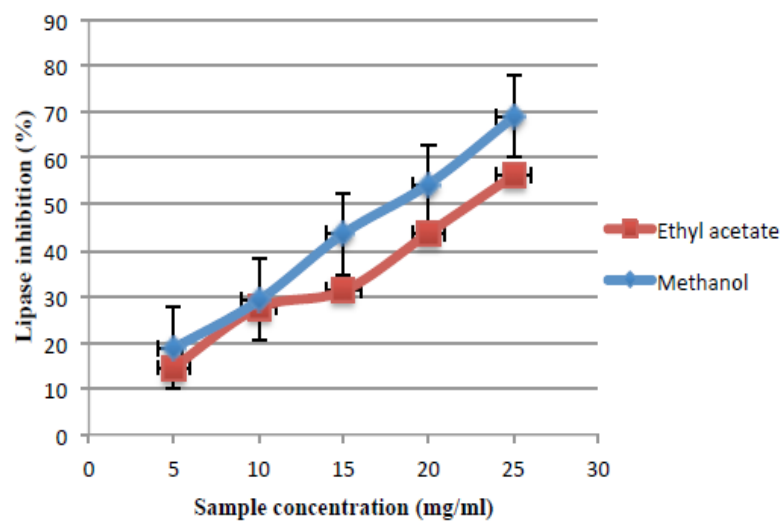

Fig. 1: Lipase inhibition of lichen Heterodermia leucomelos with different concentrations

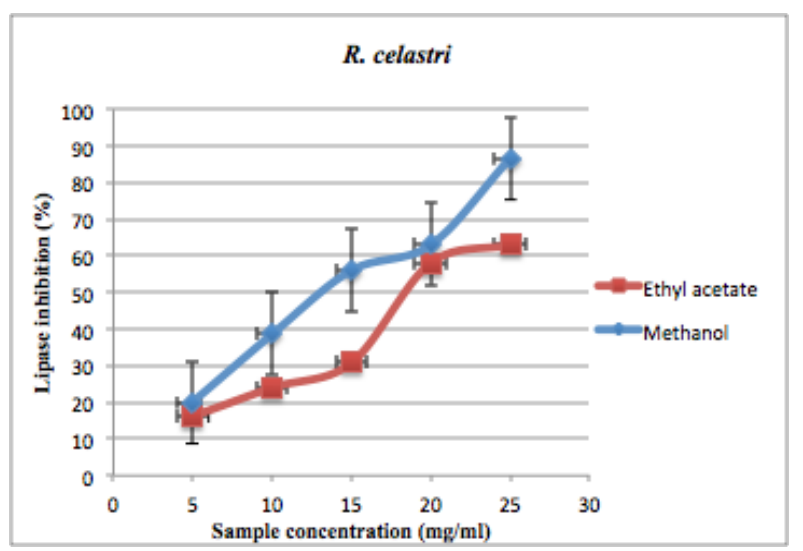

Fig. 2: Lipase inhibition of lichen Ramalina celastri with different concentrations

\section{DISCUSSION}

Pancreatic lipase or triacylglycerol acyl hydrolase, the principal lipolytic enzyme synthesized and secreted by the pancreas, plays a key role in the efficient digestion of triglycerides. Pancreatic lipase is responsible for the hydrolysis of $50-70 \%$ of the total dietary fats. It removes fatty acids from the $\alpha^{\prime}$ apdsitions of dietary triglycerides, yielding $\beta$-monoglycerides and long chain saturated and polyunsaturated fatty acids as the lipolytic products [15]. Naturally occurring compounds present an exciting opportunity for the discovery of newer anti-obesity agents. Medicinal plants have played a vital role in inhibiting pancreatic lipase in order to reduce obesity like Eleusine indica, Myristica fragrans, Melastoma candidum and Phyla nodiflora [16], Punica granatum [17], Citrullus lanatus [18], Abroma augusta [19] etc. Lichen Everniastrum cirrhatum had shown a marked inhibition of $64 \%$ at a concentration of $20 \mathrm{mg} / \mathrm{ml}$ [20]. Ramalin was isolated from Antarctic lichen Ramalina terebrata showed $25 \%$ reduced body weight when administered orally with
50-100 mg/kg to high-fat-diet-induced obese mice [21]. Ramalina celastri revealed the presence of oleic, palmitic and stearic acids as the main triacylglyceride constituents [22]; glycolipid O-alpha-Dgalactopyranosyl-(1-->6)-0-beta-D-galactopyranosyl-(1-->1)-D-glyceritol [23]; a glycosphingolipid $O$ - $\beta$-D-galactopyranosyl- $(1 \rightarrow 1)$-ceramide [24]; antitumor activity of $\alpha$-D-glucan polysaccharides with $(1 \rightarrow 3)$ $(1 \rightarrow 4)$ bonds [25]. From this study, the lichen Ramalina celastri inhibits the activity of pancreatic lipase, which indicates its protective role in treating obesity.

\section{CONCLUSION}

Obesity is characterized as abnormal or excessive fat deposition in adipose tissue and other internal organs such as liver, heart and skeletal muscle. It is a chronic disorder of carbohydrate and fat metabolism and poses a risk to the health and well-being of humans. Natural herbal products for weight reduction may be effective in the treatment of obesity and associated disorders. Consistent and safe herbal product for weight reduction is a need of developed and developing countries. Hence, in the study, an attempt has been made to test the inhibition of lipase by lichens.

\section{ACKNOWLEDGEMENT}

One of the authors (Rashmi, S.) is thankful to the University of Mysore for awarding UGC NON-NET fellowship to carry out this work.

\section{CONFLICT OF INTERESTS}

Declared none

\section{REFERENCES}

1. Roh C, Jung U. Screening of crude plant extracts with antiobesity activity. Int J Mol Sci 2012;13:1710-9.

2. Chantre P, Lairon D. Recent findings of green tea extract AR25 (Exolise) and its activity for the treatment of obesity. J Phytomed 2002;9:3-8.

3. Third Report of the National Cholesterol Education Program (NCEP) Expert Panel on Detection, Evaluation and Treatment of High Blood Cholesterol in Adults (Adult Treatment Panel III) Final Report. Circulation 2002;106:3143-421.

4. Villa-Ruano N, Pacheco-Hernandez Y, Lara-Zaragoza EB, Franco-Monsreal J. Fitoterapia: alternativa para el control de la obesidad. Elementos 2011;84:21-5.

5. Kang JG, Park C. Anti-obesity drugs: a review about their effects and safety. Diabetes Metab J 2012;36:13-25.

6. Sharma N, Sharma VK, Seo S. Screening of some medicinal plants for anti-lipase activity. J Ethnopharmacol 2005; 97:453-6.

7. Birari RB, Bhutani KK. Pancreatic lipase inhibitors from natural sources: unexplored potential. Drug Discover Today 2007;12:879-89.

8. Lowe M. The triglyceride lipases of the pancreas. J Lipid Res 2002;43:2007-16.

9. Muller K. Pharmaceutically relevant metabolites from lichens. Appl Microbiol Biotechnol 2002;56:9-16.

10. Chand P, Singh M, Mayank R. Antibacterial activity of some Indian lichens. J Ecophysiol Occup Health 2009;9:23-9.

11. Karagoz A, Dogruoz N, Zeybek Z, Aslan A. Antibacterial activity of some lichen extracts. J Med Plants Res 2009;3:1034-9.

12. Awasthi DD. A key to the macro lichens of India and Nepal. J Hattori Bot Lab 1988;65:207-302. 
13. Sahani KM, Khan IM, Chandan RC. Bovine pancreatic lipase: isolation, homogeneity and characterization. J Dairy Sci 1976;59:369-75.

14. Zheng C, Duan Y, Gao J, Ruan Z. Screening for anti-lipase properties of 37 traditional Chinese medicinal herbs. J Chin Med Assoc 2010;73:319-24.

15. Mukherjee M. Human digestive and metabolic lipases a brief review. J Mol Catal B: Enzym 2003;22:369-76.

16. Ong $\mathrm{S}$, Paneerchelvan $\mathrm{S}$, Lai $\mathrm{H}$, Rao NK. In vitro lipase inhibitory effect of thirty-two selected plants in Malaysia. Asian J Pharm Clin Res 2014;7:19-24.

17. Adnyana IK, Sukandari EY, Yuniarto A, Finna S. Anti-obesity effect of the pomegranate leaves ethanol extract (Punica granatum L.) in high-fat diet induced mice. Int J Pharm Pharm Sci 2014;6:626-31.

18. Aruna A, Vijayalakshmi K, Karthikeyan V. Pancreatic lipase inhibitory screening of Citrullus lanatus leaves. Pharma Innovation J 2014;3:44-52.

19. Gupta N, Ganeshpurkar A, Jatav N, Bansal D, Dubey N. In vitro prevention of chick pancreatic lipase activity by Abroma augusta extract. Asian Pacific J Trop Biomed 2012;2(2 Suppl):S712-S715.

20. Anilkumar HS, Kekuda PTR, Vinayaka KS, Swathi D, Venugopal TM. Anti-obesity (Pancreatic lipase inhibitory) activity of
Everniastrum cirrhatum (Fr.) Hale (Parmeliaceae). Pharmacognosy 2011;3:65-8.

21. Park B, Lee C, Jang Y, Pyo S. Anti-obese effect of ramalin in highfat-diet-induced obese mice. FASEB J 2014;28:Suppl 824, 7.

22. Fazio AT, Adler MT, Maier MS. Usnic acid and triacylglycerides production by the cultured lichen mycobiont of Ramalina celastri. Nat Prod Commun 2014;9:213-4.

23. Machado MJ, Gorin PA, Torri G, Iacomini M. The occurrence of glycolipids in the lichen Ramalina celastri. Braz J Med Biol Res 1994;27:523-6.

24. Machado MJ, Guerrini M, Gorin PAJ, Torri G, Lacomini M. A galactosphingolipid from the lichen, Ramalina celastri. Phytochemistry 1997;45:651-3.

25. Carneiro-Leão AMA, Buchi DF, Iacomini M, Gorin PAJ, Oliveira MBM. Cytotoxic effect againts HeLa cells of polysaccharides from the lichen Ramalina celastri. J Submicrosc Cytol Pathol 1997;29:503-9.

\section{How to cite this article}

- $\quad$ Rashmi Shivanna, Hengameh Parizadeh, Rajkumar H Garampalli. Invitro anti-obesity effect of macro lichens Heterodermia leucomelos and Ramalina celastri by pancreatic lipase inhibitory assay. Int J Pharm Pharm Sci 2017;9(5):137-140. 